\title{
Essential oils of Lippia sidoides and Mentha piperita against monogenean parasites and their influence on the hematology of Nile tilapia
}

\author{
Gabriela Sayuri de Oliveira Hashimoto ${ }^{a}$, Fausto Marinho Neto ${ }^{b}$, Maria Luiza Ruiz ${ }^{a}$, Monyele Acchile ${ }^{a}$, \\ Edsandra Campos Chagas ${ }^{\text {c }}$, Francisco Célio Maia Chaves ${ }^{\text {c }}$, Maurício Laterça Martins ${ }^{\mathrm{a}, *}$
}

a AQUOS - Aquatic Organisms Health Laboratory, Aquaculture Department, Federal University of Santa Catarina (UFSC), Rod. Admar Gonzaga 1346, 88040-900 Florianópolis, SC, Brazil

b Department of Veterinary Pathology, State University of São Paulo (UNESP), Via Prof. Paulo Donato Castellane, km 05, 14884-900 Jaboticabal, SP, Brazil

c EMBRAPA Western Amazon, Rod. AM 010, km 29, Zona Rural, 69010-970 Manaus, AM, Brazil

\section{A R T I C L E I N F O}

\section{Article history:}

Received 10 July 2015

Received in revised form 27 July 2015

Accepted 28 July 2015

Available online 1 August 2015

\section{Keywords:}

Fish

Phytotherapy

Rosemary pepper

Peppermint

Anti-parasitic

Blood

\begin{abstract}
A B S T R A C T
This study evaluated the use of therapeutic baths containing essential oils of Lippia sidoides (pepper rosemary) and Mentha piperita (peppermint) on the hematological parameters of Nile tilapia parasitized by the monogeneans Cichlidogyrus tilapiae, Cichlidogyrus thurstonae, Cichlidogyrus halli, and Scutogyrus longicornis. A total of 320 juvenile fish were distributed into 16 tanks of capacity $100 \mathrm{~L}$ ( 20 fish per tank), divided into 4 treatments in quadruplicates: fish exposed to a bath of $L$. sidoides at $20 \mathrm{mg} \mathrm{L}^{-1}$; fish exposed to M. piperita at $40 \mathrm{mg} \mathrm{L}^{-1}$; fish exposed only to a water bath; and fish exposed to water + DMSO (dimethyl sulfoxide) bath. The fish were subjected to 3 baths for $10 \mathrm{~min}$, at intervals of $24 \mathrm{~h}$ between treatments. After the third bath, parasitological and hematological analyses were performed. The parasite prevalence in fish treated with essential oils was seen to have decreased by $70 \%$. The efficacy attained among fish treated with L. sidoides, in comparison with control water and water + DMSO, was $1.96 \%$ and $14.16 \%$, respectively; and among fish treated with M. piperita, it was $33.33 \%$ and $41.63 \%$, respectively. The total numbers of red blood cells (RBC) and thrombocytes were lower in fish treated with $L$. sidoides. Glucose concentration and neutrophil count were significantly higher in fish treated with L. sidoides. Because of the efficacy and positive hematological results, we suggest that baths of M. piperita at $40 \mathrm{mg} \mathrm{L}^{-1}$ should be used as anthelmintic action.

Statement of relevance: Authors believe on the use of essential oils to treat ectoparasites of cultured fish and consequently no damages for hematological profile of Nile tilapia were found.
\end{abstract}

(c) 2015 Elsevier B.V. All rights reserved.

\section{Introduction}

In aquaculture, phytotherapeutics for use among farmed aquatic animals may present several advantages, such as reduced environmental impact, biodegradability, lower residue levels in animals, low toxicity, and several modes of action resulting in low likelihood of causing resistance and low cost for farmers (Soares and Tavares-Dias, 2013; Chagas et al., 2014). A recent review has shown that the use of plant extracts in aquaculture has been responsible for increased immune response and hematological and biochemical improvements (Bulfon et al., 2015).

Lippia sidoides, commonly known as rosemary pepper, is a type of bush found in northeastern Brazil that presents antiseptic and antimicrobial properties (Costa et al., 2002). Species of Lippia have been exploited in several fields such as veterinary medicine, microbiology, parasitology, zootechny, and aquaculture because of their bioactive

\footnotetext{
* Corresponding author.

E-mail address: mauricio.martins@ufsc.br (M.L. Martins).
}

potential and ease of use on a large scale (Soares and Tavares-Dias, 2013).

The genus Mentha, known as peppermint, has been exploited for its flavor and is used in medicine as an antimicrobial and antioxidant agent (Tsai et al., 2013). It produces essential oil containing menthol and several components used in the pharmaceutical and natural product industry (Kumar and Patra, 2012). Menthol is the main component after oil extraction (Freire et al., 2011; Tsai et al., 2013).

A study by Moghaddam et al. (2013) showed that Mentha piperita had antifungal activity against three species of fungi: Dreschlera spicifera, Fusarium oxysporum f.sp. ciceris and Macrophomina phaseolina. Similar data were obtained by Freire et al. (2011), who demonstrated the inhibitory potential of this essential oil against the fungi Aspergillus flavus, Aspergillus glaucus, Aspergillus niger, Aspergillus ochraceous, Colletotrichum gloesporioides, Colletotrichum musae, Fusarium oxysporum, and Fusarium semitectum.

Compared with the use of plant extracts for immunostimulant effects, they have been little used against parasites, especially against monogeneans (Bulfon et al., 2015). The anthelmintic activity of oils or plant extracts has been evaluated mainly against monogenean parasites 
of goldfish (Carassius auratus) (Steverding et al., 2005; Wang et al., 2009; Wang et al., 2010a, 2010b, 2011).

The efficacy of seed extracts from Piper guineense against the monogenean parasites Gyrodactylus and Dactylogyrus of goldfish has been studied in vitro and in vivo (Ekanem et al., 2004). Monogenean helminths are one of the most important parasites affecting fish farming and are found mainly in the gills and skin (Jerônimo et al., 2011).

Several natural substances can be used in aquaculture, but studies involving the use of extracts or essential oils in therapeutic baths against fish parasites are scarce (Reverter et al., 2014). The present study evaluated therapeutic baths using $L$. sidoides and M. piperita against monogenean gill parasites in Nile tilapia (Oreochromis niloticus), in vitro and in vivo.

\section{Material and methods}

\subsection{Essential oil extraction}

Essential oils used in this study were obtained from the leaves of $L$. sidoides and M. piperita cultured in the Section of Medicinal Plants of EMBRAPA Western Amazon situated in Manaus, AM (03 06'23.04"S and $60^{\circ} 01^{\prime} 35.14^{\prime \prime} \mathrm{W}$ ). Mean altitude is $50 \mathrm{~m}$ and mean air temperature is $25.6{ }^{\circ} \mathrm{C}$ with annual rainfall of $2200 \mathrm{~mm}$. Plants were collected in the morning and the material processed in the Medicinal Plants and Phytochemistry Laboratory of Embrapa Western Amazon, Manaus, Brazil. Oil extraction was performed by the hydrodistillation method using a Clevenger-like equipment. After that, the oils were maintained refrigerated at $-18{ }^{\circ} \mathrm{C}$ in dark glasses. Briefly, for chemical composition analysis a gas chromatograph Agilent (Palo Alto, USA) 7890A equipped with capillary column HP-5 (5\%-diphenyl-95\%-dimethyl silicon $30 \mathrm{~m} \times 0.32 \mathrm{~mm} \times 0.25 \mu \mathrm{m}$ ) was used. Temperature was programmed in 60 to $240{ }^{\circ} \mathrm{C}$, a $3{ }^{\circ} \mathrm{C} \mathrm{min}{ }^{-1}$, and using hydrogen as carrier gas $\left(1.5 \mathrm{~mL} \mathrm{~min}{ }^{-1}\right) .1 .0 \mu \mathrm{L}$ of $1 \%$ essential oil solution in dichloromethane (Merck Millipore, Darmstadt, Germany) with flux division (1:100, injector at $250^{\circ} \mathrm{C}$ ) was injected. The mass spectrum was obtained in a system Agilent $5973 \mathrm{~N}$ operated in the mode electron impact (EIMS) at $70 \mathrm{eV}$, coupled in a chromatograph Agilent 6890 using the same procedure of injection and temperature cited above. Retention indices were calculated from the retention times of the compounds and those of a serial of nalkanes $\left(C_{7}-C_{26}\right)$. Constituent identification was made by comparison of the mass spectrum obtained with the data of spectral library (Wiley 6th Ed.) and by the indices of the retention calculated and compared to published values (Adams, 2007).

\subsection{In vitro immobilization assay}

The monogenean parasites Cichlidogyrus tilapiae Paperna, 1960, Cichlidogyrus thurstonae Ergens, 1981, Cichlidogyrus halli Price and Kirk, 1976 and Scutogyrus longicornis Paperna and Thurston, 1969 were used in this assay and identified according to Douëllou (1993), Pariselle and Euzet (1995), Pariselle et al. (2003), and Thatcher (2006). The parasites were collected directly from the gills of parasitized tilapia, immediately prior to beginning assay.

Six concentrations of $L$. sidoides and $M$. piperita essential oils were used to obtain the most efficient in causing the parasite mortality. A stock solution was composed by $1 \mathrm{~g}$ of essential oils diluted in $9 \mathrm{~mL}$ of dimethyl sulfoxide (DMSO $-\mathrm{C}_{2} \mathrm{H}_{6} \mathrm{OS}$ ) in a proportion of $1: 10$.

Parasitized gill filaments of Nile tilapia were separated in sterile Petri dishes $5.5 \mathrm{~cm}$ comprising in each concentration with three replicates. From the stock solution, essential oils were diluted in $25 \mathrm{~mL}$ water to obtain $320,160,80$, and $40 \mathrm{mg} \mathrm{L}^{-1}$. For the lowest concentrations of $20 \mathrm{mg} \mathrm{L}^{-1}$ and $10 \mathrm{mg} \mathrm{L}^{-1}, 10 \mu \mathrm{L}$ in $50 \mathrm{~mL}$ and $100 \mathrm{~mL}$ water divided in $8 \mathrm{~mL}$ in each Petri dish was diluted. Two controls were used, one of them diluting $80 \mu \mathrm{L}$ DMSO in $25 \mathrm{~mL}$ water and the other only water.

For the lowest concentrations the parasites were observed each $15 \mathrm{~min}$ and for the highest concentrations (160 and $320 \mathrm{mg} \mathrm{L}^{-1}$ ) the observation was continuous. Parasites were considered dead when detected the absence of movement when stimulated with a needle or body wrinkling.

\subsection{Toxicity test}

The toxicity test aimed to evaluate the tolerance of the fish to exposure to the oil. For each concentration, three fish were used in $3 \mathrm{~L}$ of water and the oil solution was added in order to observe their behavior. Water quality was measured before and after the treatment. In situations of abnormal behavior such as agitation, anoxia, intense swimming or tipping over, the fish was immediately transferred to another bucket and the time was registered. Fish handling and samples collection were approved by Ethic Committee of Federal University of Santa Catarina (CEUA/UFSC PP00869).

\subsection{In vivo assay}

A total of 320 healthy juvenile Nile tilapia (weight of $9.76 \pm 0.48 \mathrm{~g}$ and length of $8.47 \pm 0.18 \mathrm{~cm}$ ) from the same spawning were acquired from tilapia fish farmer and acclimatized for 7 days prior to distribution into 16 circular tanks of capacity $100 \mathrm{~L}$

There were 4 treatments and 4 replicates: fish exposed to $L$. sidoides bath at $20 \mathrm{mg} \mathrm{L}^{-1}$; fish exposed to $M$. piperita bath at $40 \mathrm{mg} \mathrm{L}^{-1}$; fish exposed to water; and fish exposed to water + dimethyl sulfoxide (DMSO).

During the assay, 50\% of the water was renewed and the fish were fed three times a day with commercial dry ration for omnivorous fish, containing $28 \%$ crude protein. The water quality parameters did not alter among the treatments: temperature $27.67 \pm 0.99{ }^{\circ} \mathrm{C}$, dissolved oxygen $6.83 \pm 0.92 \mathrm{mg} \mathrm{L}^{-1}$, pH $5.86 \pm 0.65$ measured using a multiparameter portable Hanna HI9829 ${ }^{\circledR}$ (Hanna Instruments Brazil, SP), and ammonia $3.00 \pm 1.01 \mathrm{mg} \mathrm{L}^{-1}$, nitrite $0.04 \pm 0.01 \mathrm{mg} \mathrm{L}^{-1}$ and nitrate $0.70 \pm 0.22 \mathrm{mg} \mathrm{L}^{-1}$ measured by colorimetric kit Alfakit ${ }^{\circledR}$ (Alfakit, SC, Brazil).

Each treatment consisted of three baths of $10 \mathrm{~min}$ at intervals of $24 \mathrm{~h}$. The therapeutic solution was distributed at the edge of the tank: $14 \mathrm{~mL}$ of stock solution of L. sidoides; $28 \mathrm{~mL}$ of $M$. piperita solution; water alone; and water $+224 \mathrm{~mL}$ of DMSO. After the third bath, 10 fish from each replicate were collected for parasitological and hematological analysis.

\subsection{Parasitological and hematological analyses}

Fish were anesthetized in clove oil solution ( $\left.75 \mathrm{mg} . \mathrm{L}^{-1}\right)$, euthanized and the gills of 5 fish per replicate were collected for immediate parasitological analysis and the other 5 bathed in water $60{ }^{\circ} \mathrm{C}$ and fixed in alcohol $70 \%$ for posterior parasite counting. Monogenean quantification followed the method of Jerônimo et al. (2011).

The efficacy was calculated according to the formula: $\mathrm{EF}=\mathrm{MNPC}-$ MNPT $\times 100$ / MNPC (EF: efficacy, MNPC: mean number of parasites in control fish, MNPT: mean number of parasites in treated fish) (Dotta et al., 2015). Prevalence, mean intensity, and mean abundance of parasites were calculated according to Bush et al. (1997).

After fish were anesthetize the blood was withdrawn from the caudal vein with syringes containing a drop of EDTA $10 \%$ and used for blood smears stained with May Grunwald/Giemsa/Wright, hematocrit percentage, hemoglobin rate and calculated the hematimetric parameters: mean corpuscular volume (MCV), mean corpuscular hemoglobin $(\mathrm{MCH})$, and mean corpuscular hemoglobin concentration (CHCM) (Ranzani-Paiva et al., 2013). For total erythrocyte count (RBC) $5 \mu \mathrm{L}$ of the blood was diluted in $1 \mathrm{~mL}$ of fixative Dacie solution for posterior counting (Blaxhall and Daisley, 1973). Total number of thrombocytes and leukocytes (WBC) were calculated by the indirect method (Ranzani-Paiva et al., 2013). After hematocrit determination the capillary was broken at the level of white blood cells and the plasma 
transferred to refractometer for total protein determination according to Feldman et al. (2000) method. Hemoglobin concentration was analyzed in spectrophotometer Spectrum Meter ${ }^{\circledR}$ at $545 \mathrm{~nm}$ and glucose with the kit Accu-Chek ${ }^{\circledR}$.

\subsection{Statistical analysis}

The data were submitted to factorial variance analysis (ANOVA) using a Statsoft STATISTICA 7.0 software. The means among the treatments were compared at $\mathrm{p}<0.05$ significance.

\section{Results}

In this study, the essential oil of $L$. sidoides showed thymol (76.6\%) as the main compound followed by p-cimeno (6.3\%) (Fig. 1A) being identified 21 constituents representing $98.6 \%$ of the essential oil composition. Mentha piperita, showed 29 constituents and $99.5 \%$ of the essential oil composition having menthol (27.5\%), menthofurano (22.5\%), pulegone (12.8\%), menthyl acetate (12.5\%) and menthone (11.0\%) as the main compounds (Fig. 1B).

In the present assays, both $L$. sidoides and $M$. piperita had an anesthetic effect on the fish after a few minutes (Fig. 2).

In the in vitro immobilization test, the concentrations of $160 \mathrm{mg} \mathrm{L}^{-1}$ and $320 \mathrm{mg} \mathrm{L}^{-1}$ for L. sidoides and M. piperita, respectively, were the most efficient for causing parasite mortality, taking $1 \mathrm{~min}$ and $58 \mathrm{~s}$, and $8 \mathrm{~min}$ and $11 \mathrm{~s}$, respectively. Parasites exposed to water died after $4 \mathrm{~h}$ and $21 \mathrm{~min}$ and those exposed to water + DMSO after $2 \mathrm{~h}$ and $51 \mathrm{~min}$. When comparing the efficacy in relation to a water bath and water + DMSO bath there was $1.96 \%$ and $14.16 \%$ for $L$. sidoides and $33.33 \%$ and $41.63 \%$ for M. piperita, respectively (Fig. 3 ).
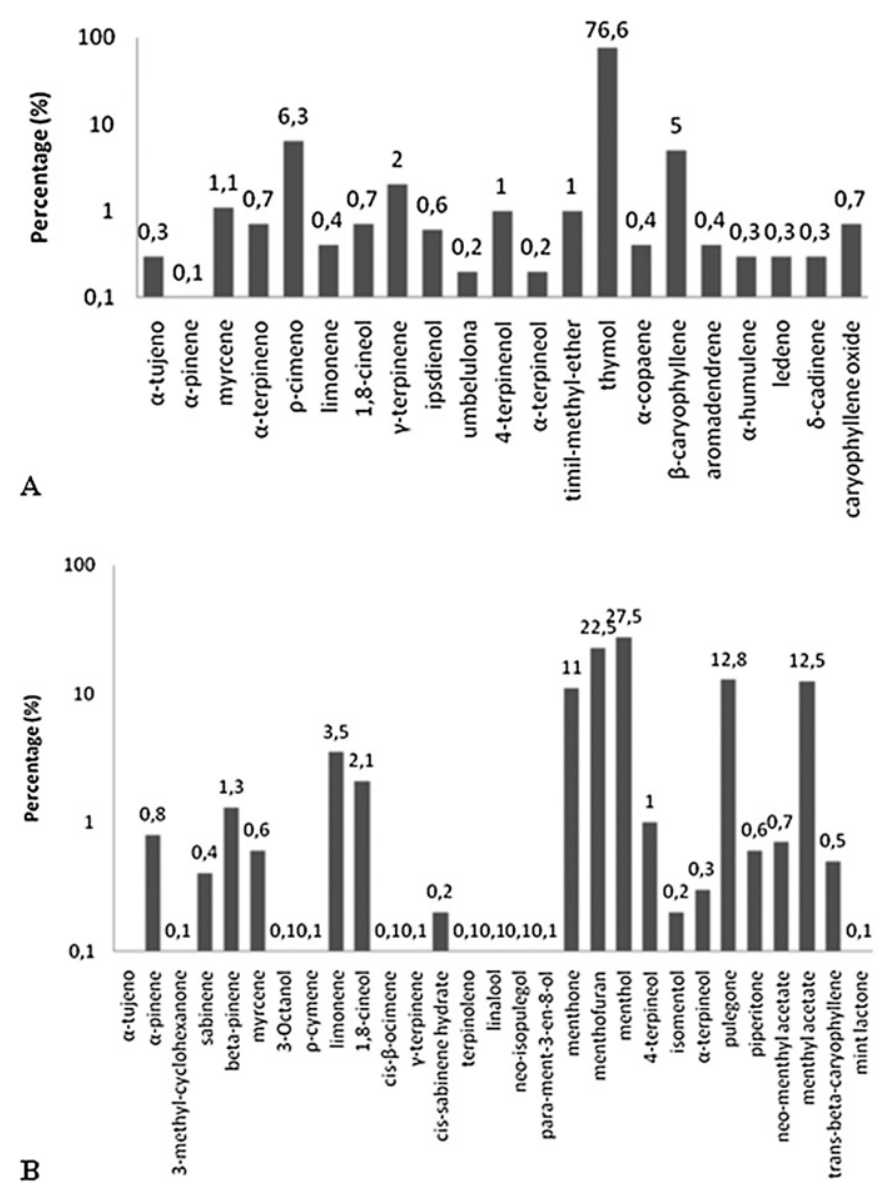

Fig. 1. Composition of essential oils used in this study. A - Lippia sidoides and B - Mentha piperita.

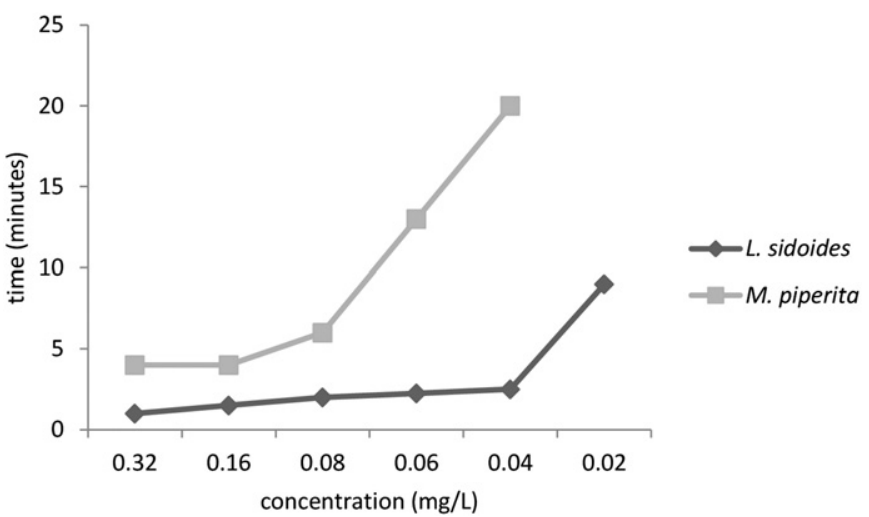

Fig. 2. Mean time for anesthetizing Nile tilapia exposed to toxicity test with essential oils of Lippia sidoides and Mentha piperita.

From the toxicity test results, the therapeutic doses were defined as $20 \mathrm{mg} \mathrm{L}^{-1}$ for $L$. sidoides and $40 \mathrm{mg} \mathrm{L}^{-1}$ for $M$. piperita (Table 1 ).

Regarding hematological parameters, an increase in hematocrit percentage accompanied by a decrease in RBC and thrombocyte count $(\mathrm{p}<0.05)$ was observed in fish treated with L. sidoides, in comparison with the water bath (Table 2). Glucose concentration and neutrophil count were significantly higher in fish treated with $L$. sidoides than in the other treatments.

\section{Discussion}

In this study, the composition of L. sidoides was similar to that found by Cavalcanti et al. (2010), who observed thymol as the main substance (80.8\%). Differently, Botelho et al. (2007) and Silva et al. (2013) found that the proportions of thymol were $56.7 \%$ and $68.40 \%$ respectively. Menthol was the main substance found in the composition of $M$. piperita in the present study (27.5\%), i.e. similar to what was reported by Tsai et al. (2013) (28.19\%) and Freire et al. (2011) (54.2\%).

According to Bakkali et al. (2008) the major compounds determine the biological essential oil activity. L. sidoides showed elevated percentage of thymol and p-cimeno. The main compound found in L. sidoides was the monoterpene thymol in which has been confirmed its antibacterial and antiparasitic potential (Bakkali et al., 2008; Oliveira et al., 2009). Menthol, the main compound found in M. piperita, is a monocyclic monoterpene that stands out for its great industrial importance with antibacterial, antifungal, and anthelminthic properties (McKay and Blumberg, 2006).

Similarly, Cunha et al. (2010) observed that Lippia alba was an efficient anesthetic for Rhamdia quelen, inhibiting an increase in the plasma cortisol level at 100 to $500 \mathrm{mg} \mathrm{L}^{-1}$. Similar results were found by Boijink et al. (2011), who used therapeutic baths of basil Ocimum

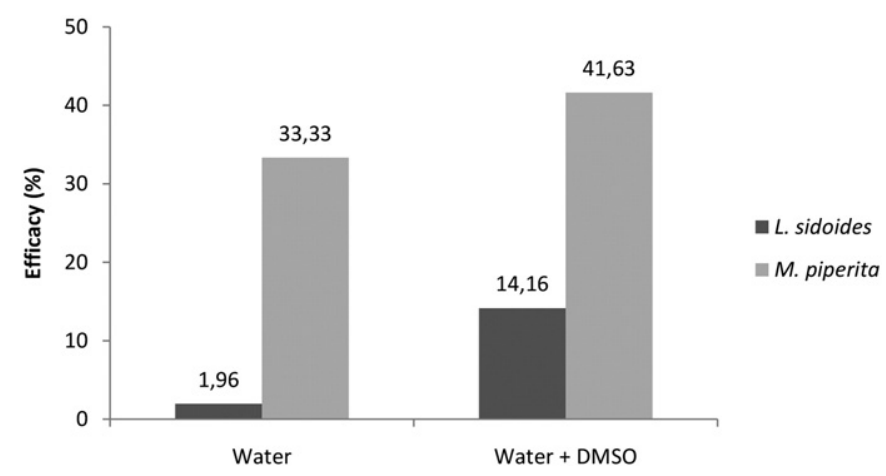

Fig. 3. Efficacy of essential oil of Lippia sidoides $\left(20 \mathrm{mg} \mathrm{L}^{-1}\right)$ and Mentha piperito ( $40 \mathrm{mg} \mathrm{L}^{-1}$ ) compared to control water and water + DMSO in therapeutic baths against monogenean parasites in Nile tilapia. 
Table 1

Prevalence values (\%), mean intensity and mean abundance ( \pm standard deviation) of monogenean parasites in Nile tilapia after therapeutic bathes of Lippia sidoides ( $20 \mathrm{mg}$ $\left.\mathrm{L}^{-1}\right)$, Mentha piperita (40 $\left.\mathrm{mg} \mathrm{L}^{-1}\right)$, water, and water + DMSO.

\begin{tabular}{lllll}
\hline & $\begin{array}{l}\text { Lippia } \\
\text { sidoides }\end{array}$ & $\begin{array}{l}\text { Mentha } \\
\text { piperita }\end{array}$ & Water & $\begin{array}{l}\text { Water }+ \\
\text { DMSO }\end{array}$ \\
\hline Prevalence (\%) & 25.0 & 27.5 & 57.5 & 60.0 \\
Mean intensity & $2.00 \pm 1.24$ & $1.36 \pm 0.67$ & $2.04 \pm 1.22$ & $2.33 \pm 1.65$ \\
Mean abundance & $0.50 \pm 1.06^{\mathrm{ab}}$ & $0.38 \pm 0.70^{\mathrm{c}}$ & $1.18 \pm 4.70^{\mathrm{bc}}$ & $1.40 \pm 1.72^{\mathrm{a}}$ \\
\hline
\end{tabular}

Different letters indicate significant difference among the treatments $(\mathrm{p}<0.05)$.

gratissimum on tambaqui (Colossoma macropomum) at $10 \mathrm{mg} \mathrm{L}^{-1}$ and $15 \mathrm{mg} \mathrm{L}^{-1}$ for $15 \mathrm{~min}$. These authors did not observe any damage among the treated fish. Even though $L$. sidoides demonstrated anesthetic activity towards Nile tilapia at lower concentrations, it could be another economic alternative for use in aquaculture.

The immobilization test was efficient, as also observed by Militz et al. (2014), in evaluating garlic extract against the monogenean Neobenedenia sp. in L. calcarifer. These authors found that the garlic suppressed embryo development, thereby reducing the eclosion and longevity of the oncomiracidium.

Similar to what was found in the present study, tea tree oil has shown potential for use against the parasite Gyrodactylus spp. in sticklebacks (Gasterosteus aculeatus) (Steverding et al., 2005). Saponins and polyphyllin D extracted from Paris polyphylla were efficient against Dactylogyrus intermedius, a monogenean parasite of goldfish (Wang et al., 2010b). The efficacy of these agents against $D$. intermedius has been shown to be variable. Wang et al. (2010a) found that the efficacy of steroidal saponins from Dioscorea zingiberensis was up to $90 \%$ and Wang et al. (2011) found that osthol extract from Radix angelicae pubescentis had efficacy of $100 \%$. On the other hand, Huang et al. (2013) reported that ethyl acetate extract from Lysima chiachristinae presented $50 \%$ efficacy against $D$. intermedius.

According to Tu et al. (2013), a bath consisting of chloroform extracts from the plant Santalum album applied to goldfish at $40 \mathrm{mg} \mathrm{L}^{-1}$ showed 100\% efficacy against the monogeneans Dactylogyrus sp. and Gyrodactylus sp.

Therapeutic bath comprising $2.9 \mathrm{mg} / \mathrm{L}$ of Azadirachta indica for 5 days reduced the numbers of the monogenean parasite Anacanthorus penilabiatus in pacu (Piaractus mesopotamicus) by $82 \%$ (Cruz et al., 2008). Similar results were found after a bath of Piper aduncum at $80 \mathrm{ml} \mathrm{L}^{-1}$ for $24 \mathrm{~h}$ applied to pirarucu (Arapaima gigas) parasitized by the monogenean Dawestrema cycloancistrium, which showed $80 \%$ efficacy (Queiroz, 2012). The study of Claudiano et al. (2009) also proved that Terminalia catappa extract was effective against the monogenean and dinoflagellate protozoan Piscinoodinium pillulare in juvenile tambaqui at $120 \mathrm{ml} \mathrm{L}^{-1}$.

A study using a diet supplemented with $0.5 \%$ and $1 \%$ propolis and Aloe barbadensis extracts showed efficacy of $83 \%$ and $85 \%$ respectively against monogenean parasites in Nile tilapia (Dotta et al., 2015). In the present study, it must be emphasized that the treatment with $M$. piperita showed the best results as an anti-parasitic agent.

Regarding the toxicity test, similar results were found by Boijink et al. (2011) after a bath with 0 . gratissimum applied to tambaqui at $10 \mathrm{mg} \mathrm{L}^{-1}$ and $15 \mathrm{mg} \mathrm{L}^{-1}$ for $15 \mathrm{~min}$, without damage to the fish. Fish treated with $L$. sidoides and $M$. piperita showed significantly lower parasite loads than those exposed to water or water + DMSO (75\% and $72.5 \%$, respectively).

As reported by Ekanem et al. (2004), the toxicity increases as the concentration administered to the fish increases. The results from steroidal saponins used as an acute toxicity assay for goldfish vary according to the compounds extracted (Wang et al., 2010b). In fact, this was confirmed in observing the difference in toxicity over time in the tests of the present study. L. sidoides showed higher toxicity than M. piperita.

Fish exposed to different environments, stress or treatments may present hematological alterations. Hematocrit percentage reflects the proportion of RBCs in the blood in relation to WBCs and plasma. On the other hand, RBCs are responsible for oxygen and carbon dioxide transport (Ranzani-Paiva et al., 2013). Greater hematocrit and lower RBC count observed in fish treated with $L$. sidoides suggest that some stressor and/or respiratory dysfunction was present, thereby suppressing the RBC count. Apart from the low RBC count in the fish treated with L. sidoides, the values for the other parameters were within the range of amplitude for the species (Tavares-Dias et al., 2009).

Reduced thrombocyte counts indicate damage to coagulation and organism defense (Martins et al., 2008). It can be inferred that the low thrombocyte counts found in fish treated with $L$. sidoides may have been associated with migration of these cells, thereby demonstrating the irritative action of the oil, as confirmed by increased neutrophil count and glucose concentration. Neutrophils are granulocytes responsible for defense of the organism (Ranzani-Paiva et al., 2013), and situations of neutrophilia in fish have been reported to be due to stress and management (Jerônimo et al., 2011) or infection (Martins et al., 2008). Glucose concentration may be affected by several factors such as stress and fish health (Ranzani-Paiva et al., 2013). It is possible that, as a result of stress caused by the treatment with $L$. sidoides, the neutrophil count and glucose concentration became altered.

\section{Conclusions}

The present study reported on the efficacy of using the essential oils of $L$. sidoides and $M$. piperita against monogenean parasites, for the first time. However, the mode of action and chemical component responsible for parasite mortality remain unknown. Although the essential oil of $L$. sidoides ( $20 \mathrm{mg} \mathrm{L}^{-1}$ ) presented efficacy, it cannot be recommended because of the hematological alterations that it caused in the fish. Use of M. piperita at $40 \mathrm{mg} \mathrm{L}^{-1}$, as a therapeutic bath, may be safe and recommendable, given that it did not cause hematological alterations. After the treatments, the fish did not show neither alterations on the body surface nor any mortality.

Table 2

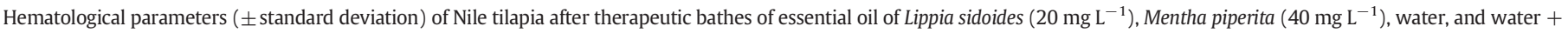
DMSO.

\begin{tabular}{|c|c|c|c|c|}
\hline Parameters & Lippia sidoides & Mentha piperita & Water & Water + DMSO \\
\hline Erythrocytes $\left(\times 10^{6} \mu \mathrm{L}^{-1}\right)$ & $1.85 \pm 0.33^{\mathrm{c}}$ & $2.79 \pm 0.50^{\mathrm{a}}$ & $2.22 \pm 0.70^{\mathrm{b}}$ & $2.76 \pm 1.08^{\mathrm{a}}$ \\
\hline Hematocrit (\%) & $28.25 \pm 3.27^{\mathrm{a}}$ & $26.50 \pm 3.66^{\mathrm{ab}}$ & $25.50 \pm 3.93^{b}$ & $27.50 \pm 3.26^{\mathrm{ab}}$ \\
\hline Hemoglobin $\left(\mathrm{g} \mathrm{dL}^{-1}\right)$ & $7.89 \pm 0.99^{\mathrm{b}}$ & $8.62 \pm 0.99^{\mathrm{a}}$ & $7.25 \pm 1.11^{\mathrm{b}}$ & $7.69 \pm 1.09^{\mathrm{b}}$ \\
\hline Total protein $\left(\mathrm{g} \mathrm{dL}^{-1}\right)$ & $5.45 \pm 0.60^{\mathrm{a}}$ & $5.40 \pm 0.40^{\mathrm{a}}$ & $5.70 \pm 0.54^{\mathrm{a}}$ & $5.40 \pm 0.46^{\mathrm{a}}$ \\
\hline Glucose $\left(\mathrm{mg} \mathrm{dL}^{-1}\right)$ & $83.00 \pm 34.19^{\mathrm{a}}$ & $65.00 \pm 15.82^{\mathrm{b}}$ & $52.50 \pm 26.12^{\mathrm{b}}$ & $51.50 \pm 34.37^{b}$ \\
\hline Leukocytes $\left(\times 10^{3} \mu \mathrm{L}^{-1}\right)$ & $91.70 \pm 37.9^{\mathrm{a}}$ & $91.45 \pm 30.46^{\mathrm{a}}$ & $107.14 \pm 46.62^{\mathrm{a}}$ & $94.77 \pm 53.85^{\mathrm{a}}$ \\
\hline Thrombocytes $\left(\times 10^{3} \mu \mathrm{L}^{-1}\right)$ & $42.12 \pm 24.01^{\mathrm{b}}$ & $89.47 \pm 34.66^{\mathrm{a}}$ & $83.30 \pm 42.12^{\mathrm{a}}$ & $90.19 \pm 68.92^{\mathrm{a}}$ \\
\hline Lymphocytes $\left(\times 10^{3} \mu \mathrm{L}^{-1}\right)$ & $85.58 \pm 35.79^{a}$ & $83.81 \pm 29.66^{a}$ & $103.35 \pm 45.10^{\mathrm{a}}$ & $87.95 \pm 50.85^{\mathrm{a}}$ \\
\hline Neutrophils $\left(\times 10^{3} \mu \mathrm{L}^{-1}\right)$ & $3.35 \pm 4.12^{\mathrm{a}}$ & $0.75 \pm 1.31^{\mathrm{b}}$ & $0.83 \pm 3.07^{\mathrm{b}}$ & $1.64 \pm 3.25^{\mathrm{b}}$ \\
\hline Monocytes $\left(\times 10^{3} \mu \mathrm{L}^{-1}\right)$ & $3.60 \pm 2.84^{\mathrm{ab}}$ & $4.78 \pm 2.59^{\mathrm{a}}$ & $2.97 \pm 2.14^{\mathrm{b}}$ & $5.29 \pm 5.43^{\mathrm{a}}$ \\
\hline
\end{tabular}

Different letters indicate significant difference among the treatments $(\mathrm{p}<0.05)$. 


\section{Acknowledgments}

The authors thank EMBRAPA (MP2-01/2012) (Brazilian Corporation of Agricultural Research) for financial support, CAPES (Coordination for the Improvement of Higher Education Personnel) for master scholarship to G.S.O. Hashimoto and CNPq (National Council of Scientific and Technological Development) for financial support and grant to M.L. Martins (CNPq 305869/2014-0) and Drs. Debora M. Fracalossi, Marcos C. Albuquerque and Natalia Marchiori (Aquaculture Department, Federal University of Santa Catarina, SC, Brazil) for critical review prior to submission.

\section{References}

Adams, R.P., 2007. Identification of Essential Oil Components by Gas Chromatography/ Quadrupole Mass Spectroscopy. 4th ed. Allured Publishing Co, Carol Stream, Illinois. Bakkali, F., Averbeck, S., Averbeck, D., Idaomar, M., 2008. Biological effects of essential oils - a review. Food Chem. Toxicol. 46, 446-475.

Blaxhall, P.C., Daisley, K.M., 1973. Routine haematological methods for use with fish blood. J. Fish Biol. 5, 771-781.

Boijink, C.L., Inoue, L.A.K.A., Chagas, E.C., Chaves, F.C.M., 2011. Boas práticas de manejo na piscicultura para conservação da qualidade ambiental: Uso de produtos naturais como anti-helmíntico em tambaqui. Produtividade agropecuária e benefícios sócioambientais das pesquisas da Embrapa Amazônia Ocidental. Resumos. Embrapa Amazônia Ocidental, pp. 41-45.

Botelho, M.A., Nogueira, N.A.P., Bastos, G.M., Fonseca, S.G.C., Lemos, T.L.G., Matos, F.J.A., Montenegro, D., Heukelbach, J., Rao, V.S., Brito, G.A.C., 2007. Antimicrobial activity of the essential oil from Lippia sidoides, carvacrol and thymol against oral pathogens. Braz. J. Med. Biol. Res. 40, 349-356.

Bulfon, C., Volpatti, D., Galeotti, M., 2015. Current research on the use of plant-derived products in farmed fish. Aquac. Res. 46, 513-551.

Bush, A.O., Lafferty, K.D., Lotz, J.M., Shostak, A.W., 1997. Parasitology meets ecology on its own terms: Margolis et al. revisited. J. Parasitol. 83, 575-583.

Cavalcanti, S.C.H., Niculau, E.S., Blank, A.F., Câmara, C.A., Araújo, I.N., Alves, P.B., 2010. Composition and acaricidal activity of Lippia sidoides essential oil against two spotted spidermite (Tetranychus urticae Koch). Bioresour. Technol. 101, 829-832.

Chagas, E.C., Majolo, C., Boijink, C.L., Chaves, F.C.M., Hashimoto, G.S.O., Figueredo, A.B., Martins, M.L., 2014. Uso de óleos essenciais e extratos no tratamento de enfermidades de peixes. In: Madi, R.R., Campos, C.M., Lizama, M.L.A.P., Takemoto, R.M. (Eds.), Patologia e sanidade em ambientes aquáticos, Massoni ed., pp. 269-294 (Maringá)

Claudiano, G.S., Dias Neto, J., Sakabe, R., Cruz, C., Salvador, R., Pilarski, F., 2009. Efficacy of aqueous extract of "Terminalia catappa" in tambaqui juveniles parasitized by monogenean and protozoan. Rev. Bras. Saúde Prod. Anim. 10 (3), 625-636.

Costa, S.M.O., Lemos, T.L.G., Pessoa, O.D.L., Assunção, J.C.C., Braz-Filho, R., 2002. Constituintes químicos de Lippia sidoides (Cham.) Verbenacea. Rev. Bras. Farmacogn. 12, 66-67.

Cruz, C., Machado-Neto, J.G., Fujimoto, R.Y., Henares, M.N.P., Duó, D.A., 2008. Efficacy of the methyl parathion and the aqueous extract of dry neem leaves in the control of Anacanthorus penilabiatus (Monogenoidea) in pacu (Piaractus mesopotamicus). Bol. Inst. Pesca 34, 61-69.

Cunha, M.A., Barros, F.M.C., Garcia, L.O., Veeck, A.P.L., Heinzmann, B.M., Loro, V., Emanuelli, T., Baldisserotto, B., 2010. Essential oil of Lippia alba: a new anesthetic for silver catfish, Rhamdia quelen. Aquaculture 306, 403-406.

Dotta, G., Brum, A., Jerônimo, G.T., Maraschin, M., Martins, M.L., 2015. Dietary supplementation with propolis and Aloe barbadensis extracts on the hematological parameters and parasitism in Nile tilapia. Braz. J. Vet. Parasitol. 24 (1), 66-71.

Douëllou, L., 1993. Monogeneans of the genus Cichlidogyrus Paperna, 1960 (Dactylogyridae: Ancyrocephalinae) from cichlid fishes of Lake Kariba (Zimbabwe) with descriptions of five new species. Syst. Parasitol. 25, 159-186.

Ekanem, A.P., Wang, M., Simon, J.E., Obiekezie, A.L., Morah, F., 2004. In vivo and in vitro activities of the seed extract of Piper guineense Schum. and Thonn. against skin and gill monogenean parasites of goldfish (Carassius auratus auratus). Phytother. Res. 18, 793-797.

Feldman, B.F., Zinckl, J.G., Jain, N.C., 2000. Schalm's Veterinary Hematology. 5th ed. Lippincott Williams e Wilkins, Philadelphia, pp. 1111-1119.

Freire, M.M., Jham, G.N., Dhingra, O.D., Jardim, C.M., Barcelos, R.C., Valente, V.M.M., 2011 Composition, antifungal activity and main fungitoxic components of the essential oil of Mentha piperita L. J. Food Saf. 32, 29-36.

Huang, A.-G., Yi, Y.-L., Ling, F., Lu, L., Zhang, Q.-Z., Wang, G.-X., 2013. Screening of plant extracts for anthelmintic activity against Dactylogyrus intermedius (Monogenea) in goldfish (Carassius auratus). Parasitol. Res. 112, 4065-4072.
Jerônimo, G.T., Laffitte, L.V., Speck, G.M., Martins, M.L., 2011. Seasonal influence on the hematological parameters in cultured Nile tilapia from southern Brazil. Braz. J. Biol. 71, 719-725.

Kumar, K.V., Patra, D.D., 2012. Alteration in yield and chemical composition of essential oi of Mentha piperita L. plant: effect of fly ash amendments and organic wastes. J. Ecol. Eng. 47, 237-241.

Martins, M.L., Mouriño, J.L.P., Amaral, G.V., Vieira, F.N., Dotta, G., Jatobá, A.M.B., Pedrotti, F.S., Jerônimo, G.T., Buglione-Neto, C.C., Pereira, J.G., 2008. Haematological changes in Nile tilapia experimentally infected with Enterococcus sp. Braz. J. Biol. 68, 631-637.

Mckay, D.L., Blumberg, J.B., 2006. A review of the bioactivity and potential health benefits of peppermint tea (Menthax piperita L.). Phytother. Res. 20, 619-633.

Militz, T.A., Southgate, P.C., Carton, A.G., Hutson, K.S., 2014. Efficacy of garlic (Allium sativum) extract applied as a therapeutic immersion treatment for Neobenedenia sp. management in aquaculture. J. Fish Dis. 37, 451-461.

Moghaddam, M., Pourbaige, M., Tabar, H.K., Farhadi, N., Hosseini, S.M.A. 2013. Composition and antifungal activity of peppermint (Mentha piperita) essential oil from Iran. J. Essent. Oil Bear. Plants 16, 506-512.

Oliveira, V.C.S., Moura, D.M.S., Lopes, J.A.D., De Andrade, P.P., Da Silva, N.H., Figueiredo, R.C.B.Q., 2009. Effects of essential oils from Cymbopogon citratus (DC) Stapf., Lippia sidoides Cham., and Ocimum gratissimum L. on growth and ultrastructure of Leishmania chagasi promastigotes. Parasitol. Res. 104, 1053-1059.

Pariselle, A., Euzet, L., 1995. Scutogyrus gen. n. (Monogenea: Ancyrocephalidae) for Cichlidogyrus longicornis minus Dossou, 1982, C. l. longicornis, and C. l. gravivaginus Paperna and Thurston, 1969, with description of three new species parasitic on African Cichlids. J. Helminthol. Soc. Wash. 62, 157-173.

Pariselle, A., Bilong, C.F.B., Euzet, L., 2003. Four new species of Cichlidogyrus Paperna 1960 (Monogenea: Ancyrocephalidae), all gill parasites from African mouthbreeder tilapias of the genera Sarotherodon and Oreochromis (Pisces, Cichlidae), with a redescription of $C$. thurstonae Ergens, 1981. Syst. Parasitol. 56, 201-210.

Queiroz, M.N., 2012. Efeito do extrato aquoso da Piper aduncum no controle de parasitas monogenóides (Plathyhelminthes: Monogenoidea) e parâmetros fisiológicos do pirarucu Arapaima gigas (Schinz 1822) Manaus, AM. (MSc) Universidade Nilton Lins/Instituto Nacional de Pesquisas da Amazônia.

Ranzani-Paiva, M.J.T., Pádua, S.B., Tavares-Dias, M., Egami, M.I., 2013. Métodos para análise hematológica em peixes. Eduem, Maringá (140 pp.).

Reverter, M., Bontemps, N., Lecchini, D., Banaigs, B., Sasal, P., 2014. Use of plant extracts in fish aquaculture as an alternative to chemotherapy: current status and future perspectives. Aquaculture 433, 50-61.

Silva, L.L., Silva, D.T., Garlet, Q.I., Cunha, M.A., Mallmann, C.A., Baldisserotto, B., Longhi, S.J. Pereira, A.M.S., Heinzmann, B.M., 2013. Anesthetic activity of Brazilian native plants in silver catfish (Rhamdia quelen). Neotrop. Ichthyol. 11, 443-451.

Soares, B.V., Tavares-Dias, M., 2013. Espécies de Lippia (Verbenaceae), seu potencial bioativo e importância na medicina veterinária e aquicultura. Biota Amazônia 3, 109-123.

Steverding, D., Morgan, E., Tkaczynski, P., Walder, F., Tinsley, R., 2005. Effect of Australian tea tree oil on Gyrodactylus spp. infection of the three-spined stickleback Gasterosteus aculeatus. Dis. Aquat. Org. 66, 29-32.

Tavares-Dias, M., Ishikawa, M.M., Martins, L.M., Satake, F., Hisano, H., Pádua, S.B. Jerônimo, G.T., Sant'ana, A.R., 2009. Hematologia: Ferramenta para o monitoramento do estado de saúde de peixes em cultivo. In: Saran-Neto, Mariano, W.S., PozzobonSoria (Eds.), Tópicos Especiais em Saúde e Criação Animal, 1ª̣ ed. Pedro \& João Eds, São Carlos.

Thatcher, V.E., 2006. Amazon Fish Parasites. 2nd ed. Pensoft, Sofia, Moscow (508 pp.).

Tsai, M.L., Wu, C.T., Lin, T.F., Lin, W.C., Huang, Y.C., Yang, C.H., 2013. Chemical composition and biological properties of essential oils of two mint species. Trop. J. Pharm. Res. 12, 577-582.

Tu, X., Ling, F., Huang, A., Zhang, Q., Wang, G., 2013. Anthelmintic efficacy of Santalum album (Santalaceae) against monogenean infections in goldfish. Parasitol. Res. 112, 2839-2845.

Wang, G.X., Han, J., Feng, T.T., Li, F.Y., Zhu, B., 2009. Bioassay-guided isolation and identification of active compounds from Fructus arctii against Dactylogyrus intermedius (Monogenea) in goldfish (Carassius auratus). Parasitol. Res. 106, 247-255.

Wang, G.-X., Jiang, D.-X., Li, J., Han, J., Liu, Y.-T., Liu, X.-L., 2010a. Anthelmintic activity of steroidal saponins from Dioscorea zingiberensis C. H. Wright against Dactylogyrus intermedius (Monogenea) in goldfish (Carassius auratus). Parasitol. Res. 107, 1365-1371.

Wang, G.-X., Han, J., Zhao, L.-W., Jiang, D.-X., Liu, Y.-T., Liu, X.-L., 2010b. Anthelmintic activity of steroidal saponins from Paris polyphylla. Phytomedicine 17, 1102-1105.

Wang, K.-Y., Yao, L., Du, Y.-H., Xie, J.-B., Huang, J.-L., Yin, Z.-Q., 2011. Anthelmintic activity of the crude extracts, fractions, and osthole from Radix angelicae pubescentis against Dactylogyrus intermedius in goldfish (Carassius auratus) in vivo. Parasitol. Res. 108, 195-200. 